\title{
Alkoholbrug, tilhør og køn blandt unge voksne i danske landområder
}

Maria Dich Herold ${ }^{1} \&$ Geoffrey Hunt ${ }^{2}$

${ }^{1}$ Center for Rusmiddelforskning, Aarhus Universitet mdh.crf@psy.au.d

${ }^{2}$ Center for Rusmiddelforskning, Aarhus Universitet gh.crf@psy.au.dk

Herold, Maria Dich; Hunt, Geoffrey (2018). 'Alkoholbrug, tilhør og køn blandt unge voksne i danske landområder' i Tidsskrift for Forskning i Sygdom og Samfund, nr. 28, 113-132

Med udgangspunkt i 140 kvalitative dybdeinterviews belyser artiklen, hvordan alkoholrelaterede praksisser udspiller sig blandt unge $i$ de danske landområder, samt hvorledes de unges alkoholbrug kan anskues i sammenhæng med forestillinger om køn og oplevelser af tilhørsforhold til lokalområdet. Således anskueliggøres det, hvordan 'sted' og 'køn', forstået som identitetsnære sociale kategorier, glider sammen og bliver medkonstituerende for de unges måder at bruge alkohol på, - og omvendt hvordan nogle former for alkoholbrug udgør en (rural) hverdagspraksis med betydning for både de unges lokalt forankrede mulighedsbetingelser og oplevelser af sig selv som kønnede individer. I konklusionen fremhæves det, at vi må have både nationale diskurser om 'udkantsdanmark' samt strukturelle forskelle mellem land- og byområder for øje i en nuanceret forståelse af, hoorfor unge på landet har andre alkoholvaner end unge i byerne. 
Alcohol use, belonging and gender among young adults in rural Denmark

On the basis of 140 qualitative in-depth interviews, this article investigates how alcohol related practices play out in the context of young people living in Rural Denmark, as well as how their alcohol use relates to notions of gender and experiences of belonging to their rural home areas. Thus, the article illustrates how 'place' and 'gender', conceptualized as identity-related social categories, intersect and co-constitute how young people in rural Denmark use alcohol, - and vice versa, how some forms of youth alcohol use form a (rural) everyday life practice of importance to rural youth's locally embedded possibilities and experiences of themselves as gendered beings. The conclusion emphasizes that national discourses on 'peripheral Denmark' as well as structural differences between rural and urban areas are important to consider in a nuanced understanding of drinking practices among young people in rural Denmark.

\section{Indledning og baggrund}

Det er et veletableret forskningsmæssigt fund, at danske unge er helt i front, når det gælder brug af alkohol: De både drikker mere og har tidligere alkoholdebut end de fleste af deres europæiske jævnaldrende (Kraus et al., 2016). Vi ved også fra både nationale og internationale undersøgelser, at unge bosat i landområder ofte drikker både mere og starter tidligere end deres jævnaldrende i byerne (Atav \& Spencer, 2002; Chan et al., 2016; Stock et al., 2010). I forlængelse af disse konklusioner er formålet med denne artikel at belyse et spørgsmål om danske unges alkoholforbrug, som vi imidlertid ikke ved særligt meget om endnu: Hvordan alkoholrelaterede praksisser ser ud og tillægges betydning blandt unge i de danske landområder? Dette ønsker vi at belyse med udgangspunkt i 140 dybdegående kvalitative interviews med danske unge mellem 18-25 år, som alle er aktive alkoholbrugere. I stedet for alene at betragte alkohol som et rusmiddel koblet til fest og beruselse i byrummet, hvilket man ofte gør i den eksisterende litteratur på ungeområdet, så tilgår vi her alkohol som et hverdagsintegrerende stof med betydning for de unges oplevelser af og bestræbelser på at føle sig hjemme, der hvor de bor. Således ønsker vi at betone, at hvis vores eksisterende forståelse af 'hvorfor unge drikker' skal nuanceres yderligere, så er det væsentligt ikke kun at konceptualisere unges forbrug af alkohol som et beruselsesfænomen koblet til byen, men også at sætte fokus på hvordan og hvorfor unge drikker alkohol i de danske landdistrikter (jf. Valentine et al., 2008). Dermed udfordres samtidig den eksisterende forskning, 
som generelt ikke tager geografiske forhold omkring unges alkoholbrug i betragtning, og som primært har byen og byliv som udgangspunkt.

Udtryk som 'den rådne banan' og 'udkantsdanmark' har indtil for nylig domineret den offentlige debat og mediedækningen af særlige områder af Danmark. Det er udtryk som vidner om, at geografiske områder er forbundet med forskellige muligheder, for eksempel hvad angår beskæftigelse, uddannelse, sundhed og offentlig transport (Agerholm \& Møller, 2011; Stine Thidemann Faber et al., 2015; Hansen \& Winther, 2015; Stock et al., 2011). Og det er udtryk, som vidner om, at geografiske områder også betydningstilskrives forskelligt og forbindes med forskellige holdninger; forskellige måder at leve livet på og forskellige ønsker for hverdagen og for fremtiden (Hansen \& Stubager, 2017; Winther \& Svendsen, 2012). Selvom danske landområder er begyndt at 'sparke igen' (Winther \& Svendsen, 2012) i takt med at der etableres alternative og mere positive fortællinger om, hvad livet på landet kan indebære, så præger fortællingen om det forfaldne og tilbagestående 'udkantsdanmark' stadig mange danskeres hverdagsforståelse af den danske geografi (Svendsen, 2015). Der eksisterer med andre ord stadigvæk geografisk definerede 'indkanter' og 'udkanter' i Danmark. Artiklen her skal netop anskues i lyset af den observation, at det på en række parametre såsom alkoholbrug har betydning, hvorvidt man lever et ungdomsliv i byen eller et ungdomsliv på landet. Det er en væsentlig betragtning, fordi den eksisterende forskningslitteratur om unges alkoholbrug, som antydet ovenstående, i vidt omfang tager udgangspunkt i, at unge drikker i forbindelse med byture: $\mathrm{i}$ byrummet, på diskoteker, i fredagsbarer og i andre urbane sammenhænge (for eksempel Bøhling, 2015; Demant \& Landolt, 2014; Olsson \& Törrönen, 2008). Vi ved med andre ord ikke ret meget om, hvordan alkoholrelaterede praksisser ser ud, eller hvilken betydning de har, når der er langt til det nærmeste diskotek, eller når der ikke ligger en ungdomsuddannelse eller et universitet i nærheden. Den eksisterende danske forskningslitteratur stiller altså stort set ikke skarpt på, hvad der foregår, når unge drikker i de danske landområder, og når landområderne inddrages, lægges der kun sparsomt vægt på geografiske betydninger og forskelle. Den internationale litteratur på området tegner dog et billede af det rurale som en kontekst, der er præget af en højere grad af alkoholbrug blandt unge, en højere grad af forældreaccept og intergenerationel brug (Chan et al., 2016; Valentine et al., 2008) samt en udpræget, men samtidig implicit, maskuliniseret drikkekultur med forskellige muligheder og implikationer for unge mænd og kvinder (Campbell, 2000; Coldwell, 2010; Dunkley, 2004; Leyshon, 2008a, b; Trell et al., 2014). Disse konklusioner kendetegner også delvist den eneste danske undersøgelse af alkoholbrug blandt 
unge på landet, vi har kunnet identificere, som har et ruralt fokus både empirisk og analytisk: At danske unge på landet statistisk set drikker mere og har tidligere alkoholdebut end unge i byerne, og hertil, at drengene på landet drikker mere end pigerne (Stock et al., 2010). I nærværende artikel sætter vi da også primært fokus på de unge mænds alkoholrelaterede praksisser. Dette skyldes delvist, at de unge mænd altså statistisk set har et større alkoholforbrug end unge kvinder, og delvist at de alkoholrelaterede rum og praksisser, der beskrives i interviewene, har en udpræget maskulin karakter.

I tillæg til ovenstående tendenser kommer desuden en forsigtig tendens til, at ungdomslivet i danske landområder i den eksisterende forskning kobles til kedsomhed og manglende fritidsmuligheder (Stock et al., 2010; Sørensen \& Pless, 2015, 2017), hvilket afspejler den opfattelse, at årsagen til det højere alkoholforbrug blandt unge på landet først og fremmest skal findes i manglen på (byens) muligheder. Vores analyser tyder imidlertid på, at alkoholforbrug blandt unge i de danske landområder ikke alene kan forklares med de unges længsel efter byen og byens muligheder eller anskues som et udtryk for kedsomhed. Selvom nogle af de unge, vi har interviewet, på landet giver udtryk for, at de keder sig eller længes væk fra deres lokalområder, så viser vores undersøgelse, at vi også må tage i betragtning, at nogle danske unge lever et ønskværdigt ungdomsliv på landet; at nogle ønsker at blive boende i deres lokalområder eller vende tilbage efter endt uddannelse; at alkoholbrug spiller en rolle i forhold til, hvordan de unge aktivt skaber og genskaber deres tilhørsforhold til lokalområdet, og at denne proces har en særlig kønnet karakter. Hertil kan man tilføje, at forskellige socioøkonomiske og uddannelsesmæssige mulighedsbetingelser mellem danske land- og byområder også ville være en relevant faktor at tage i betragtning. Dette er imidlertid ikke et centralt fokuspunkt i denne artikel.

\section{Metode og datamateriale}

Vores empiriske materiale stammer fra et igangværende kvalitativt forskningsprojekt, der netop fokuserer på unge, køn og alkoholbrug'1 . Materialet består samlet set af 140 kvalitative dybdeinterviews med unge mennesker, som er mellem 18-25 år gamle (gennemsnitsalder 21,2), og som på interviewtidspunktet har brugt alkohol indenfor de seneste 3 måneder. Selvom vi ikke fra forskningsprojektets begyndelse havde et eksplicit geografisk fokus i projektet, var vi alligevel opmærksomme på at sammensætte samplet således, at det både bestod af unge bo- 
sat i de største danske byer, mellemstore provinsbyer og landområderne. Denne diversitet i samplet har vi også ønsket at sikre på andre centrale parametre som alder, køn og uddannelse. De 140 unge, som har deltaget i projektet, er bosat på tværs af de danske regione, og har forskellige uddannelsesmæssige profiler: Nogle holder sabbatår, er ufaglærte, går på produktionsskole, teknisk skole eller har en læreplads, mens andre går på gymnasiet eller er i gang med en videregående uddannelse. De unge identificerer sig med forskellige køn: 49 \% identificerer sig som kvinde, 49 \% identificerer sig som mand, og $2 \%$ tilskriver sig en kønsidentitet, der ikke kan rummes af det traditionelle mand-kvinde kønssystem. $93 \%$ af deltagerne er født i Danmark, og 84 \% har forældre, som også er født i Danmark. $86 \%$ identificerer sig som heteroseksuelle, $6 \%$ som biseksuelle, $5 \%$ som homoseksuelle, mens $2 \%$ tilskriver sig en anden seksuel orientering. Interviewdeltagerne blev rekrutteret via en blanding af onlinerekruttering (Facebookopslag), gadeplansrekruttering (flyers, ophæng), forskellige uddannelsesinstitutione, samt snowballing. Interviewene blev udført mellem april 2015 og juni 2016 i deltagernes hjem, på vores universitetskontorer, på de unges uddannelsesinstitutioner eller andre mødesteder som for eksempel biblioteker. Under interviewene anvendte vi en semistruktureret interviewguide med henblik på at skabe kvalitative data fokuseret omkring deltagernes aktuelle livssituationer, alkoholrelaterede oplevelser, sociale, materielle og geografiske kontekster for alkoholbrug, deres subjektive og kropslige beruselseserfaringer samt deres holdninger til alkoholbrug og beruselse. I tillæg til interviewspørgsmålene anvendte vi desuden billedmateriale med det formål at facilitere alkohol- og beruselsesrelaterede fortællinger, som kunne være vanskelige for deltagerne at artikulere via direkte spørgsmål (Johnson \& Weller, 2002). Interviewene blev lydoptagede, transskriberede og herefter kodet i Nvivo 11 med det formål at organisere materialet i henhold til de overordnede tematikker og mønstre, som udsprang af deltagernes alkoholrelaterede fortællinger, for eksempel relateret til sundhed, alder og personlig udvikling, geografi- og kønsrelaterede forhold. Nogle koder var således defineret på forhånd i henhold til det overordnede forskningsprojekts fokus på køn og beruselse, mens andre koder opstod med udgangspunkt i interviewene. Deltagelsen i projektet var anonym, og alle deltagere fik biografgavekort som tak for deres deltagelse.

Det er de i alt 140 interviews, som udgør den overordnede empiriske ramme for denne artikel - og mere specifikt de interviewuddraguddrag, som på forskelligvis omhandler geografiske forhold (jf. Nvivokoden desangående). Disse interviewuddrag har vi nærlæst med henblik på at fremanalysere, hvordan geografi indgår i interviewpersonernes alkoholrelaterede fortællinger på tværs af geografiske til- 
hørsforhold. I forlængelse af dette analytiske greb lægger vi i den kommende analyse vægt på de 22 interviews med unge (7 kvinder; 15 mænd; gennemsnitsalder 20 år), som på interviewtidspunktet var bosat i et landområde - operationaliseret som et område med højst 3000 indbyggere og beliggende mindst $50 \mathrm{~km}$ fra de fem største danske byer (denne definition er inspireret af Regional- og landdistriktspolitisk redegørelse, 2013). Vores læsning af de 22 cases med unge bosat i et landområde tager udgangspunkt i et human-geografisk begreb om 'sted' (Tuan, 1979) koblet til et performativt-situationelt begreb om 'køn' (Strandell, 2000; Thorne, 1993). Således operationaliseres sted som måden, hvorpå geografiske områder og lokale praksisser tillægges mening og gives (identitetsmæssig) værdi, mens køn operationaliseres som et socialt konstitueret fænomen, der skabes og genskabes situationelt i relation til de (kønnede) mulighedsbetingelser, som gælder lokalt. Køn opfattes altså ikke som en individuelt forankret størrelse, men derimod som et fænomen, der får betydning i måderne hvorpå lokalt situerede praksisser gives mening og udspiller sig. Via disse operationaliseringer får vi mulighed for at undersøge, hvordan sted får betydning i de unges alkoholrelaterede fortællinger, samtidigmed at vi kan at undersøge de kønnede aspekter af disse fortællinger (jf. Miller \& Carbone-Lopez, 2015). Samlet set udgøres vores analyse altså dels af 1) et deskriptivt niveau med fokus på de unges alkoholrelaterede praksisser og kontekster for alkoholbrug, og 2) et fortolkende niveau med fokus på, hvordan sted og køn får betydning for måden, som de unge drikker alkohol på. For at tydeliggøre og kontrastere vores analytiske pointer vil vi undervejs i analysen også referere til de i alt 22 interviews (12 kvinder; 10 mænd, gennemsnitsalder 20,7 år), vi har foretaget med unge, som på interviewtidspunktet var bosat i København.

\section{De unges alkoholrelaterede netværk}

På tværs af køn og geografisk tilhørsforhold fortæller de 140 unge, som har deltaget $\mathrm{i}$ vores undersøgelse, at de primært drikker alkohol i forbindelse med forskellige sociale begivenheder: Når de går i byen, til fest eller på anden vis er sammen med venner, familie, kollegaer eller studiekammerater. Dette, frem for at drikke alene, kendetegner de fleste danskeres, og i særlig grad de fleste danske unges, måde at bruge alkohol på og er ikke overraskende i sig selv (Grønkjær et al., 2010). En anden ting, der er fælles for en stor del af de 140 unge, vi har interviewet, er, at deres alkoholrelaterede sociale liv i høj grad er mærket af et samfundsmæssige mobilitetskrav relateret til at uddanne sig (se for eksempel Larsen et al., 2016; 
Sørensen \& Thuesen, 2017). Det betyder, at de unge i København og andre universitetsbyer ofte referer til deres alkoholrelaterede venskabsgrupper i geografiske termer, for eksempel "gruppen fra Esbjerg" (Rosa, 24 år, København), og at de ofte organiserer en del af deres alkoholrelaterede sociale liv omkring at kunne ses med venner fra andre dele af landet; at kunne samles og "catche up" med deres jævnaldrende hjemmefra, som stadig bor i lokalområdet, eller som er påbegyndt en uddannelse et andet sted i Danmark. På samme måde fortæller en stor del af de unge i landområderne, at deres venskabsgrupper gradvist forandrer sig, fordi en del af deres jævnaldrende flytter til større byer for at uddanne sig. Dette betyder, at de er orienterede mod at besøge hinanden eller at kunne mødes og drikke alkohol sammen, når vennerne er på besøg derhjemme.

Noget, der udgør en geografisk funderet forskel i vores interviewmateriale, er, at de unge i landområderne i højere grad end de københavnske unge lægger vægt på, at deres alkoholrelaterede netværk er aldersdiverse, og at de overordnet set er mere komfortable med at drikke på tværs af generationer; at de i højere grad drikker med venner og bekendte, som er ældre end dem selv, og at de har mindre forbehold omkring at drikke alkohol sammen med forældre og andre familiemedlemmer. For eksempel fortæller Natasja (24 år, Midtjylland), at den yngste blandt de venner, som hun primært drikker med, er 21 år, mens de ældste er i fyrrene, og at alder "det er bare et tal. Hvis vi kan hygge os sammen, så er det lige meget, hvor gamle vi er". På samme måde fremhæver Jesper (20 år, Vestjylland), at alder ikke er et snit, der er afgørende for, hvem han drikker alkohol med:

"... Jamen [de] er helt op til 50 år, [dem jeg] hænger ud med. Og så ned til 15 år. Det er virkelig bredt. Det er lidt hvem, der er. Altså vi stopper tit og mødes og tager på kro med mange, der er dobbelt så gamle, som jeg er. Det er fordi, vi snakker så godt sammen alle sammen..."

Udsagn som Natasjas og Jespers kan på den ene side tolkes således, at de unge, som vælger at blive boende i deres rurale lokalområder 'er nødt til' at socialisere, og herunder at drikke alkohol, med folk, som er ældre end dem selv, simpelthen fordi en stor del af deres jævnaldrende er flyttet. Men Martins (22 år, Vestjylland) fortælling illustrerer imidlertid, at aldersdiversiteten samtidig kan kobles til fornemmelser af lokalt tilhørsforhold og mere specifikt de unges aktive og gentagende bestræbelser på at etablere følelsen af at høre til. Martin fremhæver ligesom Natasja og Jesper, at han ofte drikker alkohol i samvær med folk, som er ældre end ham selv, og at dette falder naturligt ind i hans hverdagsliv. Men hvor alkoholind- 
tag med jævnaldrende i mange tilfælde forbindes med at drikke større mængder, så er der for Martin en opmærksomhed på, at man "skal være anstændig, når man går derfra" og ikke "te sig som en 18 årig, der er til gymnasiefest", når han drikker (en) øl sammen med folk, der er ældre end ham selv. Som vi skal se senere i artiklen, kan dette handle om, at alkohol netop ikke kun bruges som et fest- og beruselsesmiddel blandt de unge, vi har snakket med i landområderne, men at det også har andre funktioner, som relaterer sig til at blive og forblive en integreret del af lokalsamfundet.

\section{Lokalområdets beværtningsmuligheder}

Et andet mønster, der træder tydeligt frem i vores materiale er, at når de unge, vi har interviewet, som bor i København, fortæller om deres alkoholbrug i relation til det sted, hvor de bor, så fremhæver de i vidt omfang det københavnske natteliv og de mange forskellige typer af barer og klubber, der findes her. Klara, som bor i København, beskriver det således:

"... der er jo Fiolstræde sådan ca. 2 minutter fra Nørreport, så det er tit $i$ Indre By, vi finder et sted at vare - bare sådan, hoor folk har lyst til at tage hen. Det er sjxldent bodega-agtigt eller en fancy klub, hoor det koster $150 \mathrm{kr}$. at komme ind. Det er gerne et sted, hoor det er gratis at komme ind, hoor man kan danse og fä noget at drikke. Det plejer at være sådan et sted, vi tager hen, men det er forskelligt, hoor det præcist er..."

Citatet formidler den pluralitet af alkoholrelaterede rum, som de fleste interviewede københavnske unge forbinder byen med. Der er med andre ord mange valgmuligheder. Det er nemt at bevæge sig rundt, det er nemt for de unge at skaffe den type alkohol, som de har lyst til at drikke, og det er i reglen også nemt at komme hjem igen. De københavnske unge fortæller, at de tager i byen, og at de drikker alkohol i byen for at hygge sig med vennerne; for at danse; for at møde nye mennesker; for at score, og de fremhæver typisk, at der er gode muligheder for at "finde de fede steder, som passer til mig", som Freja udtrykker det, eller "hvor jeg føler, jeg kan slappe af og være mig selv", som Mick siger. I interviewene gives naturligvis udtryk for forskellige præferencer, og nogle unge er mere komfortable med bylivet end andre, men overordnet set er tendensen, at de unge beskriver en stor 
tilgængelighed og mulighed for variation, hvad angår steder at gå ud og drikke alkohol.

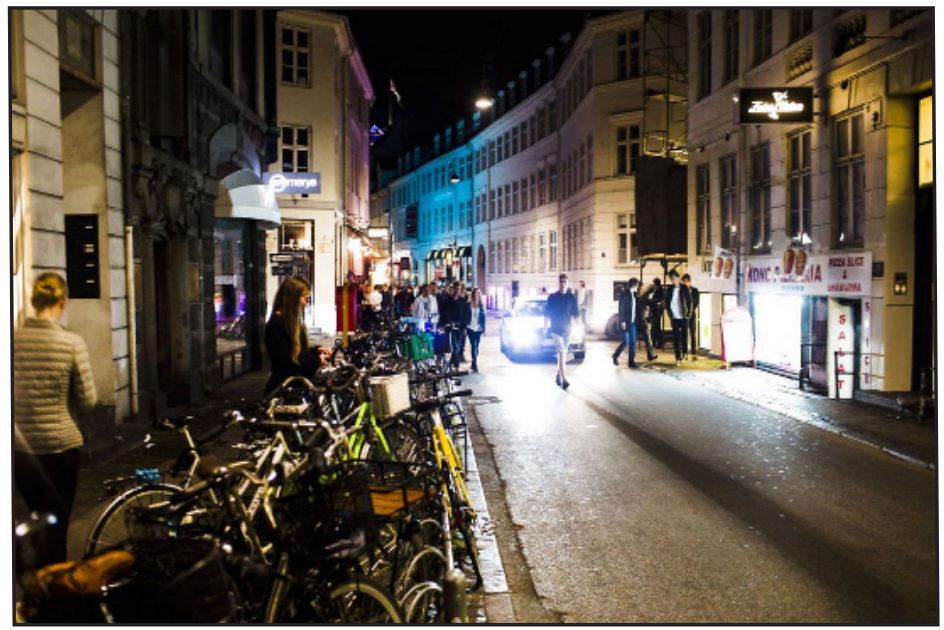

Illustration 1: Indre By. Billedet er venligst udlånt af Lea Trier Krøll.

Det giver omvendt næsten sig selv, at bar- og klubmulighederne er anderledes, hvis man bor i en lille by i et landområde. Størstedelen af de unge, vi har interviewet i landområderne, er ligesom de unge i byerne (mere eller mindre) orienteret mod at drikke alkohol i forbindelse med byture, men for unge bosat på landet gælder det, at det kan være både besværligt og dyrt at komme hjem igen, hvis turen er gået til en nærliggende lidt større by. Herudover er der også unge på landet, som benytter sig aktivt af de beværtningsmuligheder, der er tilstede i deres lokalområder. I én af de små byer, hvor vi har interviewet unge til vores undersøgelse, er der to beværtningsmuligheder: Pullerten og Agterstævnen, begge centralt beliggende barer, som har hver deres profil, men også det tilfælles at de stort set kun besøges af mænd. Dette er et kønnet aspekt af beværtningslivet, som vi generelt ikke finder beskrevet af de unge, når de fortæller om deres oplevelse af at gå ud i København, men som til gengæld kan genfindes i internationale undersøgelser af rurale drikkekulturer (for eksempel Leyshon, 2005). Så, selvom også danske og nordiske forskere helt overordnet anskuer alkoholbrug som en kønnet praksis (Demant \& Törrönen, 2011), selvom det ikke er en ny observation, at mænd og kvinders alkoholforbrug divergerer (Eriksen, 2015), og selvom også storbyens klub- og barmuligheder er præget af nogle særlige køns- og seksualitetsnormer (Buvik \& Baklien, 2016; Tan, 2014), så får det alkoholrelaterede kønslandskab tilsy- 
neladende et særligt udtryk for unge i de danske landområder. Dette vil vi forsøge at anskueliggøre i det følgende.

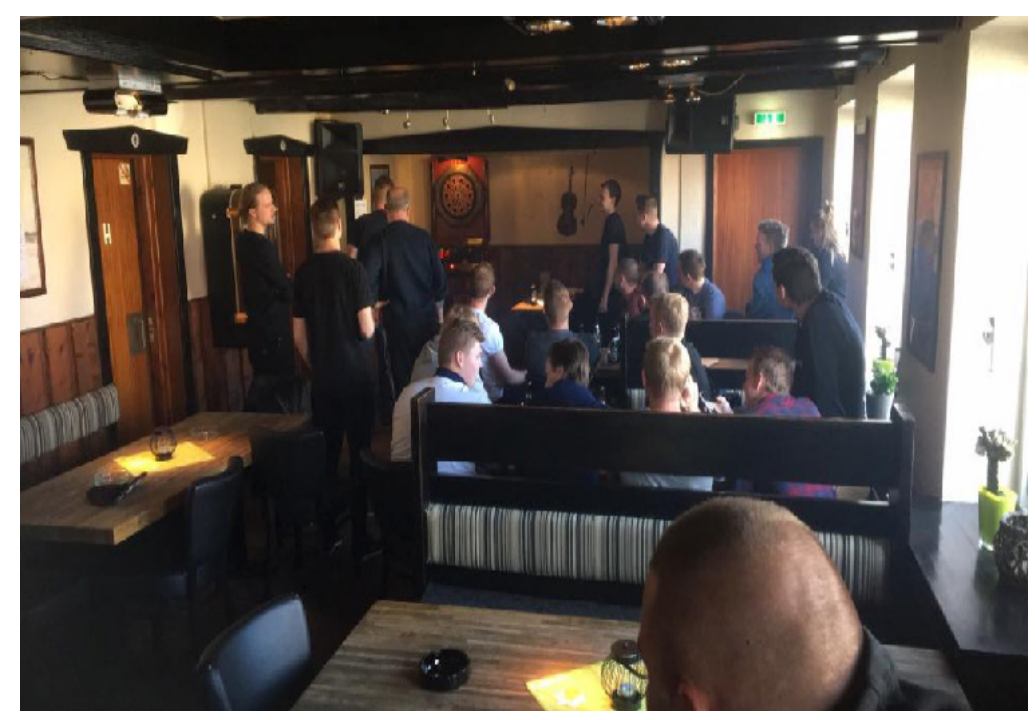

Illustration 2: Dartstævne på 'Pullerten'. Billedet er venligst udlånt af barens ejer

På Agterstæonen kommer man ifølge de unge, primært hvis man er 'stamkunde' - det vil sige, at man kommer der dagligt og typisk starter med at drikke først på dagen. Her kommer de unge sjældent, med mindre de er en del af de jagt- eller fiskerifællesskaber, som også bruger stedet. Pullerten, derimod, er for alle og for alle aldersgrupper. Pullerten bliver beskrevet som et sted, hvor man kommer efter arbejde stadig i arbejdstøj, til en fyraftensøl; hvor man mødes og spiller dart eller terninger og snakker om den forgangne uge. Et sted, hvor man indgår aftaler om at hjælpe hinanden med noget praktisk; hvor man "får en øl over snakken", som Martin (22 år, Vestjylland) udtrykker det, og hvor man desuden bruger øllen til "at slutte aftalen af":

"... de får jo fat i én og hører, om jeg lige kan hjælpe med dét og dét. Og det kan jeg da godt, det kigger vi på. Og så, når det er gjort, - eller når ham der har det hus, eller den bil eller trailer eller kutter, som vi skal lave, - når han mener, at vi er færdige for den dag, så plejer han gerne at give en ol eller to. Eller hvor mange, han nu vil af med..." 
Martins udsagn illustrerer blandt andet, at alkohol for en del af de unge, som vi har interviewet i landområderne, ikke kun forbindes med at feste og hygge sig med jævnaldrende, men også at især øllen i mange tilfælde har et liv som 'en enkelt' og fungerer som et centralt element $i$ at holde sig opdateret og integreret i lokalsamfundet. Selvfølgelig kan de unge i landområderne, ligesom de unge i byerne, planlægge en bytur, gøre sig klar, holde forfester, tage af sted, være afsted, på en eller anden måde komme hjem igen - og drikke sig fulde i løbet af hele processen. Men samtidig er deres fortællinger præget af en langt højere grad af spontanitet: At man "bliver budt" på en enkelt; at man opsøger hinanden, eller selv bliver opsøgt - spontant eller tilfældigt, som for eksempel Dennis (24 år, Vestjylland) gjorde af sin kammerat under vores interview. Som Dennis sagde, så "har jeg godt nok ikke nogle øl i køleskabet lige nu, men ellers havde jeg spurgt ham, om ikke han ville have én - så det er en naturlig del af hverdagen, jo". Dette er en betragtning, der gentages hyppigt i interviewene, også selvom det naturligvis ikke er alle unge i landområderne, der gør tingene på den måde. Hertil kommer, at unge kvinder med få undtagelser er fraværende i disse fortællinger. Eller at de, når de optræder, oftest spiller en marginal rolle, fordi de hverdagslige, spontane sammenhænge, der drikkes 'en enkelt' i, ofte er centreret omkring nogle aktivitetsformer og udspiller sig i kontekster, som i udgangspunktet opfattes som maskuline. Dette zoomer vi yderligere ind på i de følgende afsnit.

\section{Fyrrummet, værkstedet, garagen}

I interviewene udtrykkes det kun implicit af de unge mænd, at en del af de måder, der drikkes på, og de kontekster, der drikkes i, har en særlig maskulin karakter. Men de (få) unge kvinder, som har valgt at blive boende i lokalområderne, er mere eksplicitte omkring dette. For eksempel understreger Mia (21 år, Midtjylland), at "os piger herude, vi er nok generelt lidt drengede i det og kan godt lide at være sammen med gutterne [til] fyrrumsmøder og sådan noget". Fyrrumsmøderne, som Mia referer til, er en måde at drikke alkohol på, som netop tillægges en særlig maskulin værdi, og som kan genkendes i forskellige former hos en del af de unge fra landområderne. Fyrrumsmødet beskrives som en spontan hverdagsaktivitet, som altså blandt Mias venner foregår netop i fyrrummet: Den tilbygning, hvor fyret står, og som ofte minder om et lille værksted. 


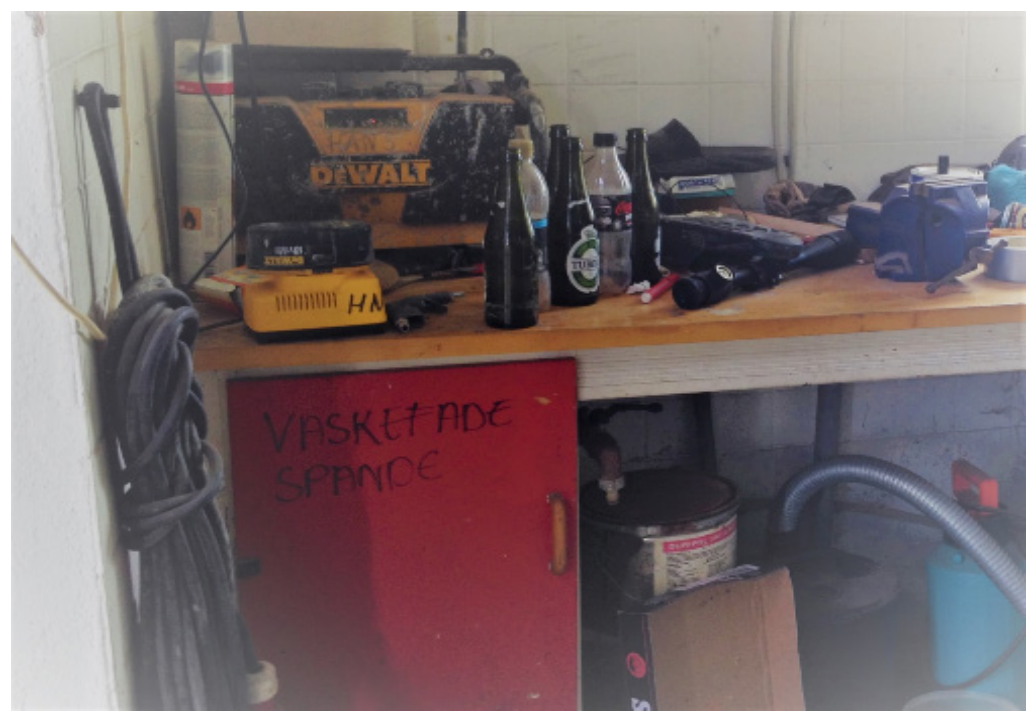

Illustration 3: Fyrrum. Billedet er taget af artiklens forsteforfatter

Fyrrumsmøderne foregår hos én af vennerne, der bor i eget hus, og finder typisk sted i hverdagene efter fyraften. Det er en særlig måde at samles på; at følge med i hinandens hverdagsliv, og det sker i udgangspunktet altid over 'en enkelt'. 'En enkelt' i denne sammenhæng kan dog sagtens involvere mere end bare en enkelt genstand, men intentionen er i udgangspunktet ikke at drikke sig beruset, selvom et fyrrumsmøde i nogle tilfælde ændrer karakter og kommer til at minde mere om en fest, som aftenen skrider frem. Fyrrumsmøderne er oftest ikke aftalt på forhånd, men man finder hurtigt ud af, hvor dagens samlingspunkt er via bilerne $\mathrm{i}$ indkørslen. Natasja (24 år, Midtjylland) giver en beskrivelse af konteksten for denne måde at drikke alkohol på:

"... Der er ikke altid stole, altså, for eksempel i går nede ved Mulle, enten sætter man sig på gulvet, eller nu sad jeg på træpillerne [som man fyrer med]. Men ellers, primært, så står man op rundt omkring. Der er ikke altid siddepladser. Ovre ved Karsten for eksempel, der er én stol. Og nu er jeg sådan lidt fin på den... Hvis ikke jeg har noget 'må gerne blive beskidt tøj' på, så vil jeg ikke være beskidt. Det der med at sætte sig op på sådan et beskidt håndværkerbord. Nej nej."

I citatet beskriver Natasja rammerne for et fyrrumsmøde, men hun lægger samtidig vægt på, hvordan hun med sin måde at være ung kvinde på håndterer netop 
fyrrumskonteksten. Ligesom Mia lægger hun ikke skjul på, at de netop i kraft af deres køn er i klart mindretal; at fyrrummet er indrettet på en måde, som byder ind til, at man har arbejdstøj på (som de unge mænd typisk har), eller at man bruger og placerer sig i rummet på nogle særlige måder. I tråd med dette fremhæver en del af de unge mænd desuden, at piger sjældent tager aktivt del i de her aktiviteter.

At kunne 'makke', det vil sige at kunne reparere og generelt have de praktiske evner til at lave noget med hænderne, bliver ikke så overraskende koblet til at være dreng eller ung mand på landet 'på den rigtige måde' (se for eksempel Bye, 2009 og Mogensen, Wulf-Andersen \& Larsen, 2017). Hertil viser vores analyse, at det ikke alene kobles til at praktisere maskulinitet på lokalt anerkendte måder, men at det samtidig kobles til at være og blive en integreret del af lokalsamfundet - for eksempel til at være én af dem, der bliver spurgt om hjælp, som Martin gav udtryk for tidligere i artiklen; og at det i samme forbindelse kobles til særlige måder at bruge alkohol, særligt øl, på. Dette giver blandt andre Jesper udtryk for:

"Nogle gange så laver vi noget for folk for at hjælpe dem. Men vi regner aldrig i penge herude. Vi regner i tjenester eller øl. Enten så skal de komme med øl, eller også så skal de lave noget for os en anden gang. [...]. Jeg laver noget for min kammerat, der er tømrer, og han laver noget tømrerarbejde for mig, når jeg har brug for noget."

Nedenstående giver Natasja (24 år, Midtjylland) endnu et eksempel på denne måde at drikke på, hvori netop det at hjælpe hinanden med noget praktisk fremhæves, og hvor det samtidig bliver tydeligt, at dette er en integreret og naturlig del af en del af de unges hverdagsliv:

"... [I går] blev Karsten hentet af Braüner, og så kørte de hjem til Braüner, fordi han lige havde fäet malet sin Opel Ascona. Så de skulle ud og køre $i$ den og finde noget selskab, og se hvor der skete noget. De er meget sådan, fyrene herude omkring... de skal helst have gang $i$ et eller andet hele tiden [...], og det kan de sagtens gøre, mens de fär øl. For eksempel i går, [da] Karsten og Braüner var ved at makke i den der Opel Ascona... Da vi kom derned, begyndte de at skille den ad og samle den igen, og den ene [blev] mere fuld end den anden..."

Ligesom værkstedet og garagen er fyrrummet et rum, der har en særlig maskulin karakter; et rum, der primært anvendes og håndteres af de unge mænd, og som $\mathrm{i}$ 
særlig grad er koblet til deres fritidsinteresser og samvær med hinanden, til deres hverdags- og fritidsliv og til at holde sig opdateret omkring hinandens foretagender. Samtidig fremhæves 'den enkelte', som nogle gange bliver til flere, i langt de fleste tilfælde som en helt central (og i sig selv maskuliniseret) faktor heri.

\section{Alkoholbrug, tilhør og køn}

Som tidligere fremhævet, så tages der primært udgangspunkt i byen og bylivet, når forskellige ungdomsrelaterede forhold belyses videnskabeligt, hvilket har fået kritikere til at påpege, at den eksisterende ungdomsforskning er præget af et metrocentrisk fokus (Farrugia, 2014). Dette har dels den implikation, at ungdomsliv på landet nemt usynliggøres, hvilket blandt andet har afledt kritiske spørgsmål om, hvorvidt der 'kun bor voksne på landet'? (Matthews et al., 2000). Men det betyder også, at de unge, der bor på landet, evalueres på en særlig måde, fordi dette dominerende perspektiv indebærer en forståelse af, at et ønskværdigt ungdomsliv leves i byen og med byens muligheder, ligesom der eksisterer en forventning om, at unge på landet bør flytte sig, og at det nemt opfattes som problematisk eller endda stigmatiserende, hvis det ikke sker (jf. Sørensen \& Thuesen, 2017). Hertil kommer desuden, at det i højere grad er unge kvinder, der flytter fra landområderne, mens en større andel af unge mænd bliver, hvilket dels bevirker, at det primært er de unge mænd på landet og deres livsførelse, der problematiseres, og dels at der simpelthen er færre unge kvinder, der deltager i for eksempel de alkoholrelaterede praksisser, som vi har beskrevet i de foregående afsnit. Overordnet kan man sige, at denne tendens indebærer den logik, at det er såkaldt ressourcestærke unge, der flytter fra landområderne, og at dette oftere er unge kvinder end unge mænd (Faber et al., 2014; Faber \& Nielsen, 2015; Nielsen, 2010; Sørensen \& Pless, 2015). Samtidig viser eksisterende forskning dog også, at unge mænd i landområderne $\mathrm{i}$ højere grad end unge kvinder føler sig tilpasse i deres hverdagsliv og tilfredse med de fritidsmuligheder, de har adgang til. At de føler en højere grad af tilhørsforhold til deres lokalområde og menneskene, de bor der med (Bloksgaard et al., 2015; Glendinning et al., 2003). Så mens unge mænd, der vælger at blive boende i landområderne, på den ene side bliver betragtet som passive, immobile og uddannelsesmæssigt indifferente, så kan man på den anden side argumentere for, at de via aktive bestræbelser formår at etablere og opretholde et positivt tilhørsforhold til deres lokalområder (Lähdesmäki et al., 2016), og at nogle i øvrigt træffer et aktivt tilvalg, når de vælger at blive boende. 
Lad os derfor se endnu nærmere på hvordan oplevelsen af og bestræbelsen på at etablere en fornemmelse af 'at høre til' sætter spor ind i de unges måder at drikke alkohol på. Dette vil vi forsøge at illustrere ved at zoome ind på en anden særlig drikke-praksis, som med forskellige termer er blevet beskrevet af en del af de unge, vi har interviewet i landområderne. Denne praksis gøres tilsyneladende også primært af unge mænd, og den er herudover eksplicit forbundet til de unges aktuelle erhverv og dermed også eksplicit til lokalområdet. Denne praksis beskrives på tværs af en del af de unge, vi har interviewet, men benævnes med forskellige termer: Siller-tur, sniger-tur, maskin-tur, land-tur og havnerundtur. Kalle (24 år, Midtjylland), som går på landbrugsskole, beskriver fænomenet således:

"Det er en bil fuld af folk og en ramme øl eller en sixpack. Og så kører man bare rundt og tjekker de lokale maskinforhandlere ud, snakker om de landbrugsmaskiner, der er til salg, og om de er noget ved. Men for vi tager afsted, så henter vi som regel en sixpack nede på tanken... Det behøver ikke at involvere maskiner dog. Det kan også bare være at kigge på køer, marker, én der spreder gylle... Det centrerer sig om, hoad vi har tilfælles herude."

Det handler altså ikke om at drikke sig beruset, men alligevel er øl en standard del af aktiviteten, ligegyldigt hvem der refererer til den og med hvilket vokabular. Det nævnes i øvrigt, for eksempel af Dennis (24 år, Vestjylland), at det "falder naturligt, at det er noget, som gutterne gør. Det er ligesom en drengeting at sidde og snakke om skibene, for eksempel, at de lige har fanget så og så mange tons fisk".

At det falder naturligt, at man hjælper hinanden - at man 'regner i tjenester' det kendetegner altså de unges beskrivelser af deres lokalsamfund og samtidig også af det dominerende maskulinitetsideal sammen med selve det at have de praktiske evner og at værdsætte og forstå den form for 'tæthed', herunder måden at bruge alkohol på, som der så ofte refereres til af de unge i interviewene. Men, dette betyder naturligvis ikke, at det er noget, som alle unge på landet agerer i henhold til. Interviewet med Krister (18 år, Vestjylland) repræsenterer et andet blik på landområderne, end vi har set indtil nu. Han går på gymnasiet, og han har ingen planer om at bosætte sig i sit lokalområde, når han bliver ældre. Han fortæller, hvordan han gradvist er vokset fra sine barndomskammerater hjemmefra, hvilket han blandt andet begrunder med deres forskellige måder at forholde sig til og bruge lokalområdet på, - herunder hvordan de bruger alkohol. Krister fortæller: 
"Det er accepteret og totalt normalt at drikke på den måde [herude]. Men jeg har distanceret mig selv fra det. De plejede at være mine bedste venner, men siden vi gik ud af folkeskolen, har jeg næsten ikke set dem, fordi det er dén måde, de er sammen på-over to øl nede på den lokale. Jeg kommer der næsten aldrig, og de kommer der flere gange om ugen. Vi er ikke uvenner, vi er bare blevet meget forskellige, tror jeg. Vi træffer forskellige livsvalg. Som jeg ser det, så skal alkoholbrug modereres, men de har en løsere tilgang til det."

Krister er anderledes orienteret end de unge, som blandt andet i kraft af deres erhvervsvalg har mulighed for at blive boende i lokalområdet; som indgår i lokalmiljøet på en anden måde; som hjælper hinanden med bilen, huset, båden; og som derfor også har en anden interesse i, at følge med i 'hvad der foregår'.

\section{Afslutning}

Som nævnt indledningsvist tager artiklen her udgangspunkt i den observation, at det på en række parametre, og herunder alkoholbrug, gør en forskel om man lever et ungdomsliv i byen eller et ungdomsliv på landet. Denne observation har relationer til både den 'udkantsdiskurs', som længe har præget mediedækningen af visse områder af Danmark, men også til det metrocentriske fokus, som præger store dele af den eksisterende ungdomsforskning, inklusive den del af feltet, som fokuserer på unges rusmiddelbrug. Blandt andet derfor ved vi i skrivende stund ikke særlig meget om, hvordan alkoholrelaterede praksisser ser ud blandt unge i de danske landområder, ligesom vi heller ikke ved særlig meget om, hvordan de betydningstillægges af de unge. Netop dette er omdrejningspunktet i denne artikel.

Selvom dét at leve et ungdomsliv på landet nemt kan kobles til en oplevelse af kedsomhed eller længsel efter byens muligheder, er en væsentlig konklusion, som udspringer af vores analyse, at en gruppe af særligt unge mænd i landområderne føler et stort tilhørsforhold til deres lokalområde, og at dette er en følelse, som de hele tiden genskaber i kraft af den måde, de engagerer sig i lokalområdet på, herunder den måde hvorpå de bruger alkohol på. Blandt andet dette indebærer, at $\mathrm{i}$ hvert fald de unge mænds måder at bruge alkohol på tilgodeser og formes af nogle særlige maskulinitetsidealer, som altså blandt andet kan sættes i relation til oplevelsen af og bestræbelsen på 'at høre til'. Samtidig er det vigtigt at fremhæve, at dette er maskulinitetsidealer, som ganske vist privilegerer nogle måder at være 
dreng eller ung mand på lokalt, og som samtidig marginaliserer eller besværliggør andre kønsudtryk, men som ikke er i høj kurs på nationalt plan. Under alle omstændigheder er det maskulinitetsformer, som en del af de unge mænd, og i øvrigt også nogle af de unge kvinder, værner om, er komfortable med og er stolte af - ligesom de er stolte af det sted, de kommer fra (se også Pedersen \& Gram, 2017). Så, mens unge mænd, der vælger at blive boende i landområderne, på den side bliver betragtet som passive, immobile og uddannelsesmæssigt indifferente, så kan man på den anden side argumentere for, at de via aktive bestræbelser formår at etablere og opretholde et positivt tilhørsforhold til deres lokalområder (Lähdesmäki et al., 2016).

Vi har i løbet af artiklen fremhævet flere gange, at (også) danske ungdomsliv overordnet set er præget af, hvad ungdoms- og uddannelsesforskere kalder et mobilitetskrav (Bloksgaard et al., 2015; Farrugia, 2016). I forhold til vores undersøgelse, så implicerer dette, at de unge, der på interviewtidspunktet bor på landet, ikke nødvendigvis bliver boende - en del, både med og uden en gymnasial uddannelse, overvejer eller er åbne i forhold til muligheden for at flytte, om end nogle også har ambitioner om at vende tilbage til landområderne efter endt uddannelse. Omvendt betyder det naturligvis også, at de unge, der bor i København og i de øvrige universitetsbyer, ikke nødvendigvis har boet der hele deres liv; en del af dem er tilflyttere fra blandt andet landområderne. Det skal også fremhæves, at københavnske unge naturligvis ikke nødvendigvis går på universitetet eller bruger byen aktivt, når de drikker alkohol, selvom muligheden forlægger på en anden måde, end den gør, hvis man som ung er bosat i et landområde. Vores analyse i denne artikel er imidlertid begrænset i forhold til at forstå de specifikke demografiske og geografiske nuancer, der forekommer i såvel landområderne som $\mathrm{i}$ København og de andre danske universitetsbyer. Den indikerer dog, at ikke alene geografiske forhold, men også hvorledes disse relaterer sig til socioøkonomiske faktorer, som de unges beskæftigelse samt uddannelsesmæssige valg og muligheder, har betydning for deres alkoholrelaterede praksisser. Dette vil være et relevant fokus i fremtidige undersøgelser om danske unges alkoholbrug.

\section{Noter}

1: Projektet er finansieret af Det Frie Forskningsråd, Samfund og Erhverv (bevillingsnummer: DFF - 4003-00035). 


\section{Referencer}

Agerholm, N., \& Møller, J. (2011). Personbefordring i landdistrikter: udfordringer og muligheder. Teknik \& Miljoe, 11.

Atav, S., \& Spencer, G.A. (2002). Health risk behaviors among adolescents attending rural, suburban, and urban schools: A comparative study. Family \& Community Health, 25 (2), 53-64. https://doi.org/10.1097/00003727-200207000-00007.

Bloksgaard, L., Faber, S.T., \& Hansen, C.D. (2015). Young in a global context: Gender, mobility and belonging in north Denmark. In S.T. Faber, \& H.P. Nielsen (Eds.), Remapping gender, place and mobility (pp. 191-205). Farnham, Surrey: Ashgate.

Buvik, K., \& Baklien, B. (2016). »Girls will be served until you have to carry them out«: Gendered serving practices in Oslo. Addiction Research \& Theory, 24 (1), 17-24. DOI:10.31 09/16066359.2015.1049536.

Bye, L.M. (2009). 'How to be a rural man': Young men's performances and negotiations of rural masculinities. Journal of Rural Studies, 25 (3), 278-288. DOI: 10.1016/j. jrurstud.2009.03.002.

Bøhling, F. (2015). Alcoholic assemblages: Exploring fluid subjects in the night-time economy. Geoforum, 58, 132-142. https://doi.org/10.1016/j.geoforum.2014.11.012.

Campbell, H. (2000). The Glass Phallus: Pub(lic) Masculinity and Drinking in Rural New Zealand. Rural Sociology, 65 (4), 562-581. DOI: 10.1111/j.1549-0831.2000.tb00044.

Chan, G.C., Kelly, A.B., Connor, J.P., Hall, W., Young, R.M., Toumbourou, J.W., et al. (2016). Regional versus urban differences in teenage alcohol use: Does parental disapproval account for these differences? Australian Journal of Rural Health, 24 (1), pp. 3-8. DOI: 10.1111/jrh.12151.

Coldwell, I. (2010). Retracted: Masculinities in the Rural and the Agricultural: A Literature Review. Sociologia Ruralis, 50 (2), 171-197. DOI: 10.1111/j.1467-9523.2009.00504.x

Demant, J., \& Landolt, S. (2014). Youth Drinking in Public Places: The Production of Drinking Spaces in and Outside Nightlife Areas. Urban Studies, 51 (1), 170-184. https://doi. org/10.1177/0042098013484532.

Demant, J., \& Törrönen, J. (2011). Changing Drinking Styles in Denmark and Finland. Fragmentation of Male and Female Drinking Among Young Adults. Substance Use E Misuse, 46 (10), 1244-1255. https://doi.org/10.3109/10826084.2011.569965.

Dunkley, C.M. (2004). Risky geographies: Teens, gender, and rural landscape in North America. Gender, Place \& Culture, 11 (4), 559-579. https://doi.org/10.1080/0966369042000307004

Eriksen, S. (2015). Ligestilling versus særstilling i kvinders alkoholkonsumtion Om udviklingen af en kvindelig alkoholkultur i velfærdsstaten. Socialmedicinsk tidskrift, 91 (6), 563-573.

Faber, S.T., Bloksgaard, L., Hansen, C.D., \& Møller, K.T. (2014). Unge på kanten: Køn, lokalitet og uddannelse. Aalborg: Aalborg University.

Faber, S.T., \& Nielsen, H.P. (Eds.) (2015). Remapping gender, place, and mobility. Farnham, Surrey: Ashgate.

Faber, S.T., Nielsen, H.P., \& Bennike, K.B. (2015). Place,(In) Equality and Gender. Nordic Council of Ministers. https://doi.org/10.6027/TN2015-558.

Farrugia, D. (2014). Towards a spatialised youth sociology: the rural and the urban in times of change. Journal of Youth Studies, 17 (3), 293-307. https://doi.org/10.1080/13676261.2013. 830700 . 
Farrugia, D. (2016). The mobility imperative for rural youth: the structural, symbolic and non-representational dimensions rural youth mobilities. Journal of Youth Studies, 19 (6), 836-851. https://doi.org/10.1080/13676261.2015.1112886.

Glendinning, A., Nuttall, M., Hendry, L., Kloep, M., \& Wood, S. (2003). Rural communities and well-being: a good place to grow up? The Sociological Review, 51 (1), 129-156.https:// doi.org/10.1111/1467-954X.00411.

Grønkjær, M., Vinther-Larsen, M., Curtis, T., Grønbæk, M., \& Nørgaard, M. (2010). Alcohol use in Denmark: A descriptive study on drinking contexts. Addiction Research $\mathcal{E}$ Theory, 18 (3), 359-370. https://doi.org/10.3109/16066350903145056.

Hansen, H.K., \& Winther, L. (2015). Employment growth, human capital and educational levels: uneven urban and regional development in Denmark 2002-2012. Geografisk Tidsskrift-Danish Journal of Geography, 115 (2), 105-118. https://doi.org/10.1080/0016722 3.2015.1034741.

Hansen, K.M., \& Stubager, R. (Eds.) (2017). Oprør fra udkanten: Folketingsvalget 2015. København: Djøf / Jurist- og Økonomiforbundet.

Johnson, J., \& Weller, S. (2002). Elicitation techniques for interviewing. In J.F. Gubrium, \& J.A. Holstein (Eds.), Handbook of Interview Research: Context \& Method (491-514). Thousand Oaks, CA.: Sage Publications.

Kraus, L., Guttormsson, U., Leifman, H., Arpa, S., Molinaro, S., Monshouwer, K., et al. (2016). ESPAD report 2015 - results from the European school survey project on alcohol and other drugs. Lisbon: EMCDDA.

Larsen, L., Wulf-Andersen, T., Nielsen, S.B., \& Mogensen, K.H. (2016). Udsatte unges uddannelsesdeltagelse: Tilhør og steder som teoretiske perspektiver. Sosiologi $i$ dag, 46 (3-4), 110-129.

Leyshon, M. (2005). No place for a girl: Rural youth pubs and the performance of masculinity. Critical studies in rural gender issues, 104-122.

Leyshon, M. (2008a). The village pub and young people's drinking practices in the countryside. Annals of Leisure Research, 11 (3-4), 289-310. https://doi.org/10.1080/11745398.200 8.9686799.

Leyshon, M. (2008b). 'We're stuck in the corner': Young women, embodiment and drinking in the countryside. Drugs: Education, Prevention and Policy, 15 (3), 267-289. https://doi. org/10.1080/09687630801920286.

Lähdesmäki, T., Saresma, T., Hiltunen, K., Jäntti, S., Sääskilahti, N., Vallius, A., et al. (2016). Fluidity and flexibility of »belonging «. Uses of the concept in contemporary research. Acta Sociologica, 59 (3), 233-247. https://doi.org/10.1177/0001699316633099.

Matthews, H., Taylor, M., Sherwood, K., Tucker, F., \& Limb, M. (2000). Growing-up in the countryside: children and the rural idyll. Journal of Rural Studies, 16 (2), 141-153. https:// doi.org/10.1016/S0743-0167(99)00059-5.

Miller, J., \& Carbone-Lopez, K. (2015). Beyond 'Doing Gender': Incorporating Race, Class, Place, and Life Transitions into Feminist Drug Research. Substance Use E Misuse, 50 (6), 693-707. https://doi.org/10.3109/10826084.2015.978646.

Mogensen, K.H., Wulf-Andersen, T., \& Larsen, L. (2017). Unge mænd og biler. Tilhør inden for og uden for skolen. Nordic Welfare Research, 2 (1), pp.39-52. DOI: 10.18261.

Nielsen, A.M.L. (2010). Taberdrenge og vinderpiger? Ungdomsforskning, 9 (3-4), 19-30. 
Olsson, B., \& Törrönen, J. (2008). Painting the Town Red: pubs, restaurants and young adults' drinking cultures in the Nordic countries. Helsinki: Nordic Centre for Alcohol and Drug Research (NAD).

Pedersen, D.H. \& Gram, M. (2017). 'The brainy ones are leaving': The subtlety of (un)cool places through the eyes of rural youth. Journal of youth studies, DOI: 10.1080/13676261.2017.1406071.

Stock, C., Bloomfield, K., Ejstrud, B., Vinther-Larsen, M., Meijer, M., Grønbæk, M., et al. (2011). Are characteristics of the school district associated with active transportation to school in Danish adolescents? The European Journal of Public Health, 22 (3), 392-404.

Stock, C., Ejstrud, B., Vinther-Larsen, M., Schlattmann, P., Curtis, T., Grønbæk, M., et al. (2010). Effects of school district factors on alcohol consumption: results of a multi-level analysis among Danish adolescents. The European Journal of Public Health, 21 (4), 449-455. https://doi.org/10.1093/eurpub/ckq156.

Strandell, H. (2000). Identitet eller interaktion - perspektiv på innebörder av kön. In H. Haavind (Ed.), Kjønn og fortolkende metode - metodiske muligheder i kvalitativ forskning (pp. 105-129). Oslo: Gyldendal Norsk Forlag.

Svendsen, G.L.H. (2015). Hvorfor bliver der talt så grimt om de danske landdistrikter?: Italesættelsen af landdistrikterne sammenlignet med de virkelige livsvilkår. In F. Slumstrup \& V. Mortensen (Eds.), Oprør Fra Udkanten 2.0 (62-79). Gjern: Hovedland.

Sørensen, J.F.L., \& Thuesen, A.A. (2017). Når unge uddannelsessøgende flytter. CLF Report Series. Esbjerg: Syddansk Universitet, Center for Landdistriktsforskning.

Sørensen, N.U., \& Pless, M. (2015). På kanten af ungdomslivet. In N.U. Sørensen, \& M. Pless (Eds.), Brydninger i ungdomslivet. Ålborg: Ålborg Universitetsforlag.

Sørensen, N.U., \& Pless, M. (2017). Living on the Periphery of Youth: Young people's narratives of youth life in rural areas. Young, 25 (4S), 1-17. https://doi.org/10.1177/1103308816669260.

Tan, Q.H. (2014). Postfeminist possibilities: unpacking the paradoxical performances of heterosexualized femininity in club spaces. Social \& Cultural Geography, 15 (1), 23-48. https://doi.org/10.1080/14649365.2013.860186.

Thorne, B. (1993). Gender play: Girls and boys in school. Buckingham: Open University Press.

Trell, E.-M., van Hoven, B., \& Huigen, P.P. (2014). 'In summer we go and drink at the lake': young men and the geographies of alcohol and drinking in rural Estonia. Children's Geographies, 12 (4), 447-463. https://doi.org/10.1080/14733285.2013.824740.

Tuan, Y.-F. (1979). Space and place: humanistic perspective. In: Gale S., Olsson G. (Eds.) Philosophy in geography (387-427) Dordrecht: Springer. https://doi.org/10.1007/978-94-0099394-5_19.

Valentine, G., Holloway, S., Knell, C., \& Jayne, M. (2008). Drinking places: Young people and cultures of alcohol consumption in rural environments. Journal of Rural Studies, 24 (1), 28-40. https://doi.org/10.1016/j.jrurstud.2007.04.003.

Winther, M.B., \& Svendsen, G.L.H. (2012). 'The Rotten Banana'fires back: The story of a Danish discourse of inclusive rurality in the making. Journal of Rural Studies, 28 (4), 466477. https://doi.org/10.1016/j.jrurstud.2012.05.003. 